\title{
An approach to manage conflicts in the construction of new transport infrastructures: the case of the Brenner $\mathrm{HS} / \mathrm{HC}$ railway line
}

\author{
F. Cavallaro ${ }^{1,2}$ \& F. Maino ${ }^{1}$ \\ ${ }^{1}$ Institute for Regional Development and Location Management, \\ EURAC European Academy of Bozen/Bolzano, Italy \\ ${ }^{2}$ School of Doctorate Studies in Regional Planning and Public Policy, \\ IUAV University of Venice, Italy
}

\begin{abstract}
The construction of new major transport infrastructures generates different and conflicting positions. In traditional decision-making processes, actors take decisions following a rigid and hierarchical framework, with the illusion of greater rapidity and lower costs. The technical argumentation is assumed as the most suitable one and different points of view are conceived against the public interest. Consequently, a conflict of polarized positions occurs, difficult to be managed. This paper, using the concepts of "framing" and "boundary object", tries to redefine the approach conceptually. The different points of view, apparently irreconcilable, are considered useful ground to develop shared decisions. Contrasts, if considered before their radicalization, can be seen as a fertile generation of shared solutions and not as a criticism. The case study of the Brenner HS/HC railway line has been chosen to illustrate this approach.

Keywords: conflicts, transport infrastructures, boundary objects, Brenner $\mathrm{HS} / \mathrm{HC}$ railway line.

\section{Introduction}

The realization of major transport infrastructures have significant consequences on the development of the territory [1]. If not well conducted, this process can generate conflicts that involve applicants, administrators, civil society and economic actors. The main point about the feasibility of such infrastructures
\end{abstract}


often involves the concept of "public interest", exploited by decision-makers as a legitimation instrument. Theoretically, this concept defines an interest that goes beyond individuality and meets a common need. In practice, it assumes a general meaning that allows widely heterogeneous interpretations. A valid parameter to determine the public interest of an infrastructure could be to either evaluate the quality of the transport service [2,3] or to quantify the potential users of the infrastructure [4]. Referring to this last point, forecasting the users is a problematic issue, mostly when the infrastructure is in its design phase. These kinds of ex ante estimates are often largely overestimated [5]: more than 90 percent of the cases analysed are well below the figures measured ex post. Methodological issues are not the only causes of such biased estimates: they can be voluntarily overestimated to reduce criticisms. The choices are mainly justified using technical argumentations, which are difficult to deny. Furthermore, they circumvent the real issues and generate misunderstandings and conflicts between different perspectives. The rigidity of the different positions escalates due to the non-inclusive decision-making process.

In Italy, the traditional decision-making process is strongly non-inclusive: developments are provided and then presented to the public, but only when decisions have already been made. This "DEAD" approach (the acronym of Decision, Education, Announcement and Defense [6]) favours decision-makers and postpones, or even omits, a real discussion with citizens.

According to EU transport policy, in Italy numerous major transport infrastructures are in a design, planned or realized phase: they are part of the socalled Trans European Networks-Transport (TEN-T), an integrated system of infrastructures that aims at encouraging the modal shift from road to rail. Most of these infrastructures are a cause of local opposition, the reason being that tensions can violently explode (e.g., Dal Molin airport, Turin-Lyon and RomeMilan high-speed lines [7-9]). In other cases, when juxtapositions are not as extreme, decision-makers consider different actors' opinions as not relevant and do not take them into account, with the illusion of greater rapidity and lower costs. In many of these cases, conflicts remain latent with the risk that a hard-line opposition forms when it is least expected.

The paper analyses the case of the new Brenner high-speed/high-capacity (HS/HC) railway line. The Alps are a sensitive transit area in the centre of the European Union. Brenner, as one of the most important transalpine corridors, is heavily affected by traffic and its environmental impacts. Its special and unique geomorphology with narrow valley, high gradients in the road network combined with special climatic phenomena and situations turns it into a hotspot for air pollutant emissions and noise, which can be five times higher than in plain. The $\mathrm{HS} / \mathrm{HC}$ railway line foster the shift of both freight and passenger traffic towards a more sustainable mode of transport. Hence, if well managed, the construction of the infrastructure could guarantee relevant impacts on the alpine environment.

The BBT, the core part of the infrastructure, has recently entered its main building phase, with the positive judgment of the Environmental Impact Assessment (EIA) required by law. It followed a hierarchical decision-making process and some criticisms have already risen but it does not yet present a 
radicalized conflict. The political front strongly supports the realization of the infrastructure and apparently only minor actors seem to be against the project. If not correctly managed, the process could explode as the cases previously mentioned have.

The purpose of this paper is twofold: first, to assert the importance of a shared approach to the problem as a basis to prevent and recompose conflicts regarding the construction of new infrastructures [10]; second, to provide a method aimed at a better overview about the stances of the involved actors. The paper is organized by the following format. Section 2 describes the theoretical framework in detail. Section 3 illustrates the case study of the Brenner HS/HC railway line. Section 4 collects actors' different points of view, illustrating the criticisms and the local public involvement in Prati di Vizze. A legislative analysis of the Italian condition (Section 5) aims to explain the criticisms, highlighting the different approaches in comparison with other European countries. In Section 6, some final considerations regarding the methodology are provided.

\section{Theoretical framework}

A more rigorous and inclusive process implies the switch from a pure technical analysis to a more comprehensive approach. Pinch and Bijker [11] propose the adoption of the "social constructivism" approach, where the technical knowledge depends also on a community's endorsement: a problem exists, if it is considered critical by a relevant social group. For this reason, the analysis of the winning idea and its genesis is not enough to evaluate the social role of an object and an analysis of the deviation from the final version is required. For example, the history of the bicycle reveals some technical cul-de-sacs. However, even if they were a technical failure, they concurred in defining its current shape and functionality and therefore must not be ignored. For these kinds of analyses, the usual approach follows the concept of translation, derived from Callon and Latours' Actor-Network theory and extended to the entire sociological theory by Law [12]. It is based on the creation and definition of strategic "alliances", normally coincident with the winner's perspective.

In the case of potential processes where the final effect is unknown, stances are different and there are more considered viewpoints, a vision that is "successful" in keeping out other perspectives is not allowed. Star and Griesemer [13] propose an alternative method based on the concept of translation as well. It does not provide a single answer but uses boundary objects, which are shared problems treated with different points of view. In spite of their complexity, there are common traits that make problems recognizable: the authors suggest that these elements should be the basis to redefine a problem rather than the solution. Hence, using boundary objects requires an analysis of the different points of view. The frames theory [14] is very useful to this aim: it represents the actors' cultural and values frameworks. Different frames could converge in a shared vision of the problem by a boundary object properly configured. This approach is presented in the next section for the HS/HC Brenner railway line. 


\section{The Brenner corridor}

The Brenner corridor is the main link through the Alps between Germany, Austria and Italy. Because of its central position in the middle of the alpine arc and the restrained altitude of the pass, the Brenner historically represents one of most important transalpine connections. This condition persists today: in recent years, the Brenner has been the most used alpine transnational corridor for both passenger and freight (in 2011, freight was over 42.2 million tons [15]).

The Brenner axis is currently composed of two transnational infrastructures: the Munich-Verona railway and the European road Munich-Verona. The latter consists of the A22 Modena-Brenner highway (Italy), the A12 and A13 BrennerKufstein highways (Austria) and the A93 highway (Germany). Furthermore, the EU is supporting the realization of a third infrastructure: the HS/HC railway line, central part of the TEN-T $\mathrm{n}^{\circ} 1$ Berlin. It is divided into three main parts (figure 1):

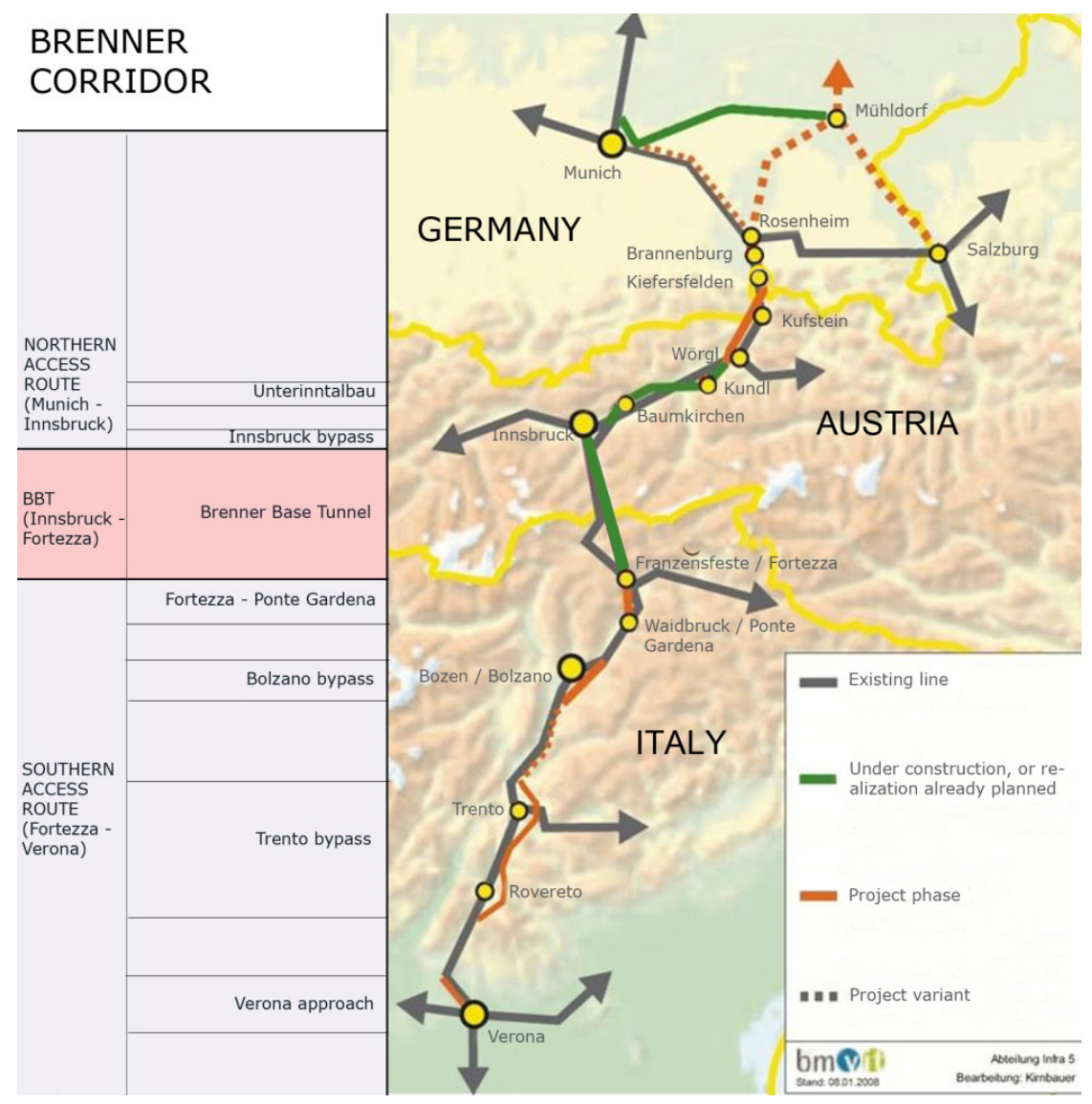

Figure 1: The Brenner corridor [16]. 
- Northern line (Munich-Innsbruck) is the most critical stretch. Hard slopes, narrow radii of curvature and barely extendable, rock tunnels limit the maximum speed to $80 \mathrm{~km} / \mathrm{h}$ (in some cases, the speed is limited to $40 \mathrm{~km} / \mathrm{h}$ ). Furthermore, the lines directed to Arlberg and Zell am See use this section, thus determining a large daily train circulation. The enhancement of the line began in 2003 and is currently in an advanced phase.

- Brenner Base Tunnel (BBT): a 55-km base tunnel between Fortezza and Innsbruck (32 km of the infrastructure are in Austria and $23 \mathrm{~km}$ are in Italy). The BBT decreases the distance of the present line by $20 \mathrm{~km}$ between Innsbruck and Fortezza, bypassing many critical stretches. These characteristics fulfil the minimum standards required for $\mathrm{HS} / \mathrm{HC}$ lines, halving the travel times between Bolzano and Innsbruck.

- Southern line (Fortezza-Verona). Due to a lower priority, this stretch is still in a planning phase. It should be operational by 2030 and consist of $240 \mathrm{~km}$ (of which 220 are tunnelled) sorted into eight parts and built in different phases.

Estimated costs for the Italian side of the overall line are 38 billion $€$. The BBT represents the most expensive and important piece of infrastructure on the entire line: in some cases, there is a coincidence between the whole HS/HC line and the tunnel. In 2001, the Interministerial Committee for Economic Planning (CIPE) included the BBT in its list of high priority, national infrastructure projects. The work was approved in 2007. During the same year, preliminary excavation workings for the exploration tunnel began. Since March 2012, excavation for the main tunnels have begun as well. In 2025, the initiation of the operation phase is planned. The EU ( 27 percent), Italy ( 36.5 percent) and Austria (36.5 percent) cover the costs for the BBT. In 2012, Italian costs are forecasted at 8 billion $€$. BBT SE is the European public joint-stock company that is building the tunnel and will manage its operative phase. Tunnel Ferroviario del Brennero Holding S.p.A. represents the Italian quote of BBT SE (50 percent). Its shareholders are Rete Ferroviaria Italiana (85.29 percent), the Autonomous Provinces of Trento and Bolzano (6.24 percent each) and the Province of Verona (2.24 percent). In Austria, the Österreichische Bundes Bahn (ÖBB) is the only shareholder, with the remaining 50 percent of the corporation's stock.

\section{Different points of view}

Recalling the framework methodology [14], the decision to build the Brenner $\mathrm{HS} / \mathrm{HC}$ railway line generated four main points of view, which correspond to likewise different frameworks.

The EU, national governments, the Alps Convention, many local administrations and Legambiente (this last contains many specifications), support the first point of view. The actors are grounded on the assumption of the major sustainability provided by the new $\mathrm{HS} / \mathrm{HC}$ line due to the lower unitary emissions of rail mode. Because of their orography, mountain areas greatly suffer from congestion and pollution (up to five times higher than level ground). In order to limit such emissions, it is necessary to realize a new base tunnel and a 
new railway line along the Brenner corridor, connected with the European network. The line is mainly tunnelled and far from residential areas. It will not segregate the valley and will absorb part of the road traffic, mostly freight, if appropriate political measures are adopted [17-19]. Work must begin immediately, to be ready for when the network will be saturated (by the year 2022, according to the traffic growth expressed in table 1). These forecasts are based on the "trend" scenario ("business-as-usual" rules). For further information about this scenario, interested readers may refer to [20, 21].

Table 1: Traffic increase expected along Brenner corridor [20].

\begin{tabular}{|c|c|c|c|c|}
\hline \multicolumn{5}{|c|}{ Brenner growth rates - trend scenario } \\
\hline \multirow{2}{*}{ Year } & \multicolumn{2}{|c|}{ Trend scenario } & \multicolumn{2}{c|}{ Trend scenario } \\
\cline { 2 - 5 } & Road & Road & Road & Rail \\
\hline $2010-2015$ & $1.2 \%$ & $1.2 \%$ & $1.2 \%$ & $3.1 \%$ \\
\hline $2016-2020$ & $1.9 \%$ & $1.9 \%$ & $1.9 \%$ & $4.8 \%$ \\
\hline $2021-2025$ & $1.9 \%$ & $1.9 \%$ & $1.9 \%$ & $4.5 \%$ \\
\hline $2026-2030$ & $1.4 \%$ & $1.4 \%$ & $1.4 \%$ & $3.8 \%$ \\
\hline
\end{tabular}

The current line cannot accommodate new traffic, since its travel times are not competitive with road transport. Modernizing the line is very expensive and in some places, not technically feasible [22]: the new line is the only solution. Coherently with the Alps Convention's transportation protocol, the new HS/HC line is supposed to be the only infrastructure able to grant this sustainable development.

The Brenner Highway, Chamber of Commerce of Bolzano and Bolzano Dolomiti Airport support the second point of view. They consider the first point of view unsatisfactory, since it does not address the accessibility problem and create the possibility for the economic development of Bolzano adequately [23, 24]. They propose a more robust infrastructural approach, where the BBT and $\mathrm{HS} / \mathrm{HC}$ line are only two elements of a more complex system that includes the addition of a third lane to highway A22 and the enlargement of the airport of Bolzano.

A polar vision is sustained by those actors (mostly at local level) who fear the loss of space and identity for the valley that the line will cross and who are worried about unjustified costs for the public (third point of view). They argue that the alpine valleys will be reduced to crossing-spaces, increasingly difficult to be inhabited and with a reduced attractiveness [25]. The solution is to rationalize and improve the existing infrastructures and to not create a new one. The "Brenner Action Plan", already approved and under realization, aims to improve the capability of the historical line to 244 trains per day, similarly to the $\mathrm{HS} / \mathrm{HC}$ line. New policies, which favour the use of the current railway line and discourage road transport, should provide a more sustainable transport system without new infrastructures. Currently, the fee for a truck on the Brenner highway costs much less (about $9 \mathrm{cent} / \mathrm{km}$ ) than the mean transalpine axis price (70-80 cent $/ \mathrm{km})$. Unavoidably, truckers choose this highway, thus causing 
increases in traffic and congestion. In this framework, new transport infrastructures are not a primary goal because of a variety of problems [26]. The first set of issues is social, e.g., HS/HC lines subtract space to inhabitants. The second are environmental, e.g., many hectares of productive land will be lost. Aquifers could dry and uranium lodes may be found. Moreover, building sites will be active for a long time (at least 15-25 years), thus causing lengthy difficulties for the inhabitants. Next, economic issues such as that the socioeconomic development grants benefits mostly at the macro level. Local activities suffer from such kinds of large infrastructures, which usually benefit areas far away from their location. The last set of problems is monetary: public costs are too high. Projects that are more useful in other fields would be a better monetary investment.

The fourth point of view involves an economic approach, based on a traditional cost-benefit analysis. Analysed data would confirm that BBT is a useful infrastructure only if the current railway line is saturated effectively [27]. Between the great infrastructures currently in planning phase, the Brenner $\mathrm{HS} / \mathrm{HC}$ line is undoubtedly the most relevant and should be the main matter of the European economic efforts.

It is clear that such points of view are very different. However, it does not imply that a shared definition of the problem cannot be found. Recalling the boundary objects, the concept of sustainability is common to every viewpoint. Through this concept and its different interpretations, we should rethink the debate about the construction of the infrastructure (table 2).

A similar approach has been adopted for the Gronda di Ponente, an urban highway realized in Genoa [28]. Even if the viewpoints were contrasted, the final result has been a shared solution, the outcome of the negotiation of different

Table 2: The different points of view about the Brenner HS/HC railway line.

\begin{tabular}{|c|c|c|c|c|}
\hline $\begin{array}{l}\text { BOUNDARY } \\
\text { OBJECT }\end{array}$ & PROBLEM & SCALE & SOLUTION & ACTORS \\
\hline \multirow{4}{*}{ Sustainability } & $\begin{array}{l}\text { Lack of economic } \\
\text { development and } \\
\text { circulation right for } \\
\text { citizens; transport } \\
\text { externalities }\end{array}$ & Europe & $\begin{array}{l}\mathrm{HS} / \mathrm{HC} \text { rail } \\
\text { line }\end{array}$ & $\begin{array}{l}\text { European Union, Italian } \\
\text { and Austrian Government, } \\
\text { some local public } \\
\text { administrations, Alpine } \\
\text { Convention }\end{array}$ \\
\hline & $\begin{array}{l}\text { Lack of } \\
\text { accessibility = lack } \\
\text { of economic } \\
\text { development }\end{array}$ & Bolzano & $\begin{array}{l}\mathrm{HS} / \mathrm{HC} \text { rail } \\
\text { line, airport, } \\
\text { A22 third } \\
\text { lane }\end{array}$ & $\begin{array}{l}\text { Chamber of Commerce } \\
\text { Bolzano, Brenner } \\
\text { Highway S.p.A., Airport } \\
\text { Bolzano Dolomiti S.p.A. }\end{array}$ \\
\hline & $\begin{array}{l}\text { Pollution and lack } \\
\text { of space for } \\
\text { mountain regions }\end{array}$ & $\begin{array}{l}\text { Alpine } \\
\text { valleys }\end{array}$ & $\begin{array}{l}\text { Improvement } \\
\text { of existing } \\
\text { railway lines } \\
\text { discouraging } \\
\text { road transport }\end{array}$ & $\begin{array}{l}\text { Environmental and social } \\
\text { associations, some local } \\
\text { public administrations, } \\
\text { South Tyrolean } \\
\text { association of farmers }\end{array}$ \\
\hline & Economic benefit & $\begin{array}{l}\text { Brenner } \\
\text { axis }\end{array}$ & $\begin{array}{l}\mathrm{HS} / \mathrm{HC} \text { rail } \\
\text { line }\end{array}$ & Economic evaluators \\
\hline
\end{tabular}


interests. So far, the realization of the BBT and Brenner HS/HC line has not been supported by shared intents between the actors. Even if until now juxtapositions have not become extreme, recently many associations asked for a stop in construction activities in order to open a legitimate public debate. Dr. Bergmeister, president of BBT SE, replied that more than one hundred informative evenings have been organized. Many opponents to the project state that these presentations only aimed to justify choices already taken [29]. A referendum to decide the future of the line has been proposed as well, but it has not been accepted at the political level. Indeed, the right of reply was rarely admitted. A partial exception can be considered the meetings of Prati di Vizze (South Tyrol) and Trento (Trentino). Particularly, the meeting in Prati di Vizze is paradigmatic of the latent conflicts [30]. This municipality was chosen as the location to realize a $3.7 \mathrm{~km}$ secondary tunnel to transport material, access the main tunnel and for a 500,000 mc deposit. Citizens of Prati di Vizze were particularly critical about the original project. After an official petition, an informative meeting and vigorous protests, in 2008, a variation of the project was approved, and the deposit was moved from Prati di Vizze to Mules and Steinach. This event did not gain much prominence, except for participative propaganda. It has been as a success of a participatory method, as confirmed by the Italian Ministry of the Infrastructures in a recent interview (August, 2013): "the method adopted for the BBT is excellent: involvement of the municipalities and population, quality of the project, collaboration between institutions". Furthermore, several technical studies, such as the analyses on $\mathrm{CO}_{2}$ emissions to evaluate the environmental impacts [31-33] have been carried out around this infrastructure. However, these useful tools only add support to the decision and not a validation of the project.

The case of Prati di Vizze reveals the nature of the problem and the potential criticisms that could occur, when the construction of the line will be extended also to the two other Provinces involved (Trento and Verona). The next section highlights one of the causes of such criticisms, expanding the Italian legislative framework and comparing it with other European nations.

\section{Normative framework}

The EU determines the realization of a main transnational infrastructure like the Brenner HS/HC railway line. During the planning phase, "the Union's activities shall take into account the potential economic viability of the projects" [34]. This vague article has been integrated with the decision $n^{\circ} 884 / 2004$. This decision states that a common interest project has to be potentially valid from an economic perspective, based on a socioeconomic cost-benefit analysis (CBA). CBA becomes the method to evaluate the public interest of an infrastructure, as adopted by the Italian DPR 2007/2010, article 14. Nevertheless, the socioeconomic elements seem to be excluded from the preliminary analysis and those studies are not accessible to the public.

However, it is at the national level that the main problems (and differences between countries) are visible. In Italy, the CIPE decides the priority for each 
infrastructure of national interest. The iter begins with a preliminary project, where route and characteristics of the line are defined. At this stage, an EIA must be included. The project is then evaluated by the so-called "enlarged" CIPE. This also includes the Presidents' Autonomous regions and Provinces with special statute, which previously discussed the project with the municipalities involved.

After the approval, the "definitive project" (D. lgs. 163/2006) has to be prepared: it consists of several technical documents and projects, including the "conferenza dei servizi", where local administrations are invited to send remarks and propositions. Private citizens have the right to propose observations about the expropriation plan. Italian law prefers a centralized procedure: through its executive institution (the CIPE), it takes upon the thankless task to almost exclusively judge the entire practice. The case of the EIA is emblematic: in the ordinary law, it is conceived as a fundamental tranche of the public participation process. Indeed, main infrastructures deserve a hastened procedure ("accelerated" EIA), which sacrifices public participation [35]. Furthermore, even if regions or provinces negatively judge the EIA, an opposing opinion from the Superior Council for the Public Works is enough to reject their judgment. Aware about these criticisms, two Italian regions introduced experimental participative procedures: Liguria (with law 39/2007) and Toscana (with law 69/2007). The methodology adopted in these regions has produced very positive participatory results [36], even if main infrastructures have already been decided before the introduction of this law and a final evaluation cannot be given.

It is interesting to compare the Italian procedure with that of other adjoining nations. Switzerland is known to be one of the most rigorous nations in transport policy. The transnational high-speed railway project ("NFTA") was approved in the early 90s. It included two main corridors (Lötschberg and Gotthard) and four base tunnels. After the approval from Parliament, three opposition committees promoted a referendum to evaluate the willingness of the citizens, according to the Swiss constitution. In 1992, about 46 percent of the population voted in this referendum, confirming the decision made by Parliament. This vote was also the basis for a second referendum, called "Alpine Initiative". This initiative, approved in 1997, modified the Swiss constitution with the duty to transfer freight traffic from road to railway, thus referring not only to the realization of new infrastructures but also on the policies related within this. In 1998, a further referendum was launched and approved: the realization of NFTA by "steps" was discussed and the introduction of a tax on heavy traffic proportional to performances (TTPCP) to fund more than 50 percent of the works. This tax was introduced in 2001 for vehicles over 3.5 tons circulating along the Swiss road network. Only after this last referendum, and with the approval of the majority of the population, did the works for the Gotthard base tunnel officially begin (1999). The infrastructure will be likely concluded in 2017, one year before the original project forecasts. Ten years after the introduction of these policies, results appear to be encouraging. UFT [15] estimates that 64 percent of freight traffic moves by rail, while the remaining 36 percent is by road. If compared with Austria (32.5 percent rail and 67.5 percent road) and France (14.3 percent rail and 85.7 percent road), the effectiveness of the adopted measures are clear. 
In France, all projects of national relevance require a path with preliminary double consultation: the debate publique and the enquete publique [9]. Debate publique was introduced as the first phase of consultancy in 1995. It is a general discussion over the socioeconomic and environmental features of the infrastructure involving administrators, actors and associations. It is preparatory to the preliminary project and its maximal length is one year. Over $300 \mathrm{Mio} €$ is compulsory, between 150 and 300 Mio $€$ is discretionary. When the debate ends, the commission drafts a final balance, which the public administration must take into consideration. Administrators then must insert the answers required during the public debate into their considerations. This is the only way to realize the preliminary project. Enquete publique is the second participatory phase and includes the public remarks on the preliminary projects. The commissary (neutral figure) drafts a final report, with his non-binding opinion on the project. The project may receive the certification of public utility, and the definitive phase can begin only after these steps have been completed.

\section{Conclusions}

The realization of new major transport infrastructures implies relevant environmental and socioeconomic impacts in the territory. The Italian approach to the problem is narrow-minded and uncompromising, in stark contrast with the conventions of the UN (e.g., the Aarhus Convention, 1998), many European directives and even Italian Regional laws that increasingly attempt to make the decisional process on environmental and urban planning more accessible to the public. The decision-making process must be inclusive by providing maximum publicity of the various project phases and the stakeholders' involvement should be included as early as possible, in order to avoid radicalized positions. The integration of different points of views from the beginning of the process develops common ground and shared decisions, and improves the backing of results. It contributes to quality assurance and easier implementation of the projects. From an economic perspective, this reduces the final costs and has significant timesaving effects.

The method proposed in this paper analyses the case study of the HS/HC Brenner railway line, describes the points of view of different actors and provides a method for a shared approach to this problem as a basis to prevent and recompose conflict regarding the construction of new infrastructures. The method proposed is derived from the framework theory, as formulated by Schön and Rein [14] and boundary objects, as described by Star and Griesemer [13]. This has been able to prove how apparently irreconcilable positions in advanced phases derive from certain interpretative attitudes. By using an adequate approach, the actors can find a common ground for dialogue and propose a less unidirectional perspective than early ones. This does not necessarily require a participative process but implies at least a "legitimation of the problem" [37] and provides a great base/fertile ground for an eventually more inclusive process. This approach can be included in the process of "territorialization" [25]. It is the production of territory by social actors and must especially consider the local 
scale. In this process, all of the different dimensions and interests have a determinant role, both of subject and role and perhaps of context. Complexity of relations can only increase.

To conclude, two main antithetical cases can theoretically occur: the first is dyadic, with authorities and protesting groups holding opposing positions; the second envisages multiple interactions where diversities are a common challenge. Only in this last case may conflicts produce positive effects, with a constructive role and contributing in defining an infrastructure's usefulness for the public good [10].

\section{References}

[1] Cappelli A., Libardo A., Nocera S., Teorie, strategie ed iniziative per lo sviluppo dei servizi di trasporto pubblico regionale/Theories, Strategies and Actions for the Efficient Development of Regional Transit. Ingegneria Ferroviaria 68-11: 943-962, 2013.

[2] Nocera S., Un approccio operativo per la valutazione della qualità nei servizi di trasporto pubblico/An Operational Approach for Quality Evaluation in Public Transport Services. Ingegneria Ferroviaria 65-4: 363383, 2010.

[3] Nocera S., The key role of quality assessment in public transport policy. Traffic Engineering \& Control 52-9: 394-398, 2011.

[4] Libardo A., Nocera S., Transportation Elasticity for the Analysis of Italian Transportation Demand on a Regional Scale. Traffic Engineering and Control 49-5: 187-192, 2008.

[5] Flyvbjerg, B., Skamris Holm M.K., Buhl S.L., Inaccuracy in Traffic Forecasts. Transport Reviews, Vol. 26, No. 1, 1-24, 2006.

[6] Hartz-Karp J., Understanding Deliberativeness: Bridging Theory and Practice, in International Journal of Public Participation, Volume I, Issue 2, December 2007.

[7] Cappelli, A., Il nuovo corridoio ferroviario Torino-Lione/The new railway corridor between Turin and Lyons, Ingegneria Ferroviaria 61-6: 495-504, 2006.

[8] Caruso L., Il territorio della politica. La nuova partecipazione di massa nei movimenti. No Tav e No Dal Molin, Franco Angeli, Milano, 2010.

[9] Cullino R., Fabrizi C., Senza la base non si può cantare. La nuova linea ferroviaria Torino-Lione nell'esperienza italiana e francese. Proceedings of the XXXII Italian conference of Regional sciences, $15^{\text {th }}-17^{\text {th }}$ September 2011, Turin, 2011.

[10] Hirschmann, A.O., I conflitti sociali come pilastri della società di mercato democratiche. In Hirschmann, A.O., Autosovversione, Il Mulino, Bologna, 1997.

[11] Pinch T.J., Bijker W.E., The Social Construction of Facts and Artefacts: Or How the Sociology of Science and the Sociology of Technology Might Benefit Each Other. Social Studies of Science, Vol. 14, No. 3 (Aug., 1984), pp. 399-441, 1984. 
[12] Law, J., Notes on the Theory of Actor-Network: Ordering, Strategy, and Heterogeneity. Systems Practice 5, 379-393, 1992.

[13] Star S.L., Griesemer J.R., Institutional ecology, translations and boundary objects: Amateurs and professionals in Berkeley's Museum of Vertebrate Zoology, in Social Studies of Sciences n. 19, pp. 387-420, 1989.

[14] Schön D., Rein M., Frame Reflection: Toward the resolution of intractable policy controversies, Basic Books, New York, 1994.

[15] Ufficio Federale Dei Trasporti (UFT), Alpinfo, Traffico merci su strada e ferrovia attraverso le Alpi. Berna. Online: www.bav.admin.ch [01-042013], 2012.

[16] Bundesministerium für Verkehr, Innovation und Technologie (BMVIT) (2008). Lageplan Gesamtstrecke der Achse München-Verona.

[17] Cappelli A., Nocera S., Freight modal split models: data base, calibration problem and urban application. In: Brebbia C.A. \& Dolezel V. (Editors): Urban Transport XII - Urban Transport and the environment in 21st Century. The Wit Press, Southampton, UK. ISBN: 1-84564-179-5. ISSN: 1746-4498, 2006.

[18] Nocera S., Cavallaro F., Economical Evaluation of Future Carbon Impacts on the Italian Highways. Proced Soc Behav Sci 54: 1360 - 1369, 2012.

[19] Nocera S., Tonin S., A Joint Probability Density Function for reducing the Uncertainty of Marginal Social Cost of Carbon Evaluation in Transport Planning. Advances in Intelligent Systems and Computing, 2013 (in press).

[20] ProgTrans, Previsione del traffico merci e passeggeri attraverso l'arco alpino con focalizzazione sul valico del Brennero. Rapporto di ricerca, 2007.

[21] Nocera S., Cavallaro F., Policy Effectiveness for Containing $\mathrm{CO}_{2}$ Emissions in Transportation. Proced Soc Behav Sci 20: 703-713, 2011.

[22] BBT SE, Motivazione progetto ed alternative. Online: http://www.bmvit.gv. at/verkehr/eisenbahn/verfahren/bbt/bbt2/D011802366.pdf [01.04.2013], 2008.

[23] Donatini O., Alto Adige, 21 ottobre 2011. Online: http:/altoadige.gelocal.it /cronaca/2011/10/21/news/frattini-bolzano-e-strategica-ma-ebner-manca-1aeroporto-1.4296132, [01.04.2013], 2011.

[24] Istituto di ricerca economica (IRE), Le infrastrutture di trasporto in Alto Adige. CCIAA Bolzano, Online: http://static.repubblica.it /altoadige/pdf/infrastrutture-in-altoadige.pdf, [01.04.2013], 1997.

[25] Bobbio L., Dansero E., La TAV e la valle di Susa. Geografie in competizione. Allemandi, Torino, 2008.

[26] Poliandri G., Campedelli C., No alla nuova linea ferroviaria ad alta velocità e alta capacità Brennero Verona. Online: http://www.stopbbt.it/web/documenti/x_dossier_notav_full.pdf [01.04.2013], 2008.

[27] Grimaldi R., La galleria di base del Brennero: considerazioni su costi e benefici. In: Grimaldi R., 2012. C'è luce in fondo al tunnel? Analisi e spunti sulle politiche infrastrutturali ferroviarie alpine. Maggioli, Rimini, 2012. 
[28] Pucci P., Large infrastructure and conflicts in Italy: searching boundary objects. International research conference, Berlin, 2011.

[29] Gamper L., Grandi opere e l'esempio BBT: Sfide per le Pubbliche amministrazioni. In: Grimaldi R., 2012. C'è luce in fondo al tunnel? Analisi e spunti sulle politiche infrastrutturali ferroviarie alpine. Maggioli, Rimini, 2012.

[30] Niro M., Eurotunnel, viaggio nella protesta della Val di Vizze. QT n. 167. Online: http://www.questotrentino.it/qt/?aid=10828, [01-04-2013], 2007.

[31] Cavallaro F., Maino F., Morelli V., A new method for forecasting $\mathrm{CO}_{2}$ operation emissions along an infrastructure corridor European Transport $\backslash$ Trasporti Europei (2013) Issue 55, Paper n 4, ISSN 1825-3997, 2013.

[32] Nocera S., Cavallaro F., A methodological framework for the economic evaluation of $\mathrm{CO}_{2}$ emissions from transport. J. Adv. Transp. 2013. DOI: 10.1002/atr.1249

[33] Nocera S., Maino F., Cavallaro F., A heuristic Method for evaluating CO2 Efficiency in Transport Planning. European Transport Research Review 4: 91-106, 2012.

[34] European Union, Consolidated version of the treaty on the functioning of the European Union. Online: http://eur-lex.europa.eu/LexUriServ/LexUri Serv.do?uri =OJ:C:2010:083:0047:0200:EN:PDF , [01.04.2013], 2010.

[35] Pizzanelli, G., La partecipazione dei privati alle decisioni pubbliche. Politiche ambientali e realizzazione delle grandi opere infrastrutturali. Giuffrè editore, Milano, 2010.

[36] IRPET, Partecipazione, politiche pubbliche, territorio. La L.R. 69/2007. Online: http://www.consiglio.regione.toscana.it:8085/leggi-e-banche-dati/ valutazione-e-controllo-leggi/relazione_partecipazione.pdf , [01.04.2013], 2011.

[37] Blumer H., Social problems as collective behaviour, British Journal of Political Science, n. 18, p. 298-306, 1971. 